\title{
Effect of heat treatments on precipitate microstructure and mechanical properties of CuCrZr alloy
}

Singh, B.N; Edwards, D.J.; Tähtinen, S.

Publication date:

2004

Document Version

Publisher's PDF, also known as Version of record

Link back to DTU Orbit

Citation (APA):

Singh, B. N., Edwards, D. J., \& Tähtinen, S. (2004). Effect of heat treatments on precipitate microstructure and mechanical properties of CuCrZr alloy. Risø National Laboratory. Denmark. Forskningscenter Risoe. Risoe-R No. $1436(\mathrm{EN})$

\section{General rights}

Copyright and moral rights for the publications made accessible in the public portal are retained by the authors and/or other copyright owners and it is a condition of accessing publications that users recognise and abide by the legal requirements associated with these rights.

- Users may download and print one copy of any publication from the public portal for the purpose of private study or research.

- You may not further distribute the material or use it for any profit-making activity or commercial gain

- You may freely distribute the URL identifying the publication in the public portal

If you believe that this document breaches copyright please contact us providing details, and we will remove access to the work immediately and investigate your claim 
Risø-R-1436(EN)

\section{Effect of Heat Treatments on Precipitate Microstructure and Mechanical Properties of CuCrZr Alloy}

B.N. Singh, D.J. Edwards and S. Tähtinen 
Authors: B.N. Singh ${ }^{1)}$, D.J. Edwards ${ }^{2)}$ and S. Tähtinen ${ }^{3)}$

Title: Effect of Heat Treatments on Precipitate Microstructure and Mechanical Properties of CuCrZr Alloy

Department: Materials Research Department

${ }^{1)}$ Materials Research Department, Risø National Laboratory DK-4000 Roskilde, Denmark

${ }^{2)}$ Materials Structure and Performance Group, Pacific Northwest National Laboratory, Richland, WA 99352, USA

${ }^{3)}$ VTT Industrial Systems

FIN-02044 VTT, Finland

\section{Abstract}

A number of specimens of CuCrZr alloy was prime aged and then overaged at $600^{\circ} \mathrm{C}$ for 1,2 and 4 hours and for 4 hours at 700 and $850^{\circ} \mathrm{C}$. After different heat treatments, both the precipitate microstructure and mechanical properties were characterized. Mechanical properties were determined at 50 and $300^{\circ} \mathrm{C}$. Some selected specimens in the prime aged as well as overaged conditions were irradiated in the BR-2 reactor at $\mathrm{Mol}$ at 60 and $300^{\circ} \mathrm{C}$ to a displacement dose level of $\sim 0.3 \mathrm{dpa}$. Irradiated specimens were mechanically tested at 60 and $300^{\circ} \mathrm{C}$. The post-deformation microstructure of the irradiated specimens was examined in the transmission electron microscope. Results of the present investigations are presented in section 3. A brief summary of the main results and conclusions is given in section 4.
Risø-R-1436(EN)

December 2004

ISSN 0106-2840

ISBN 87-550-3278-8 (internet)

Contract no.: TW1-TVV-COP

(EFDA)

Groups own reg.no.

1610013-00

Sponsorship:

EU-Fusion Technology Programme

Cover:

Pages: 24

Tabels: 3

References: 2

Risø National Laboratory

Information Service Department

P.O. Box 49

DK-4000 Roskilde

Denmark

Telephone +45 46774004

bibl@risoe.dk

Fax +45 46774013

www.risoe.dk 


\section{Contents}

Abstract

1 Introduction 5

2 Materials and Experimental Procedure 5

3 Results 6

3.1 Microstructure 6

3.2 Tensile properties 7

3.3 Post-deformation microstructure 9

3.4 Fracture toughness behaviour 9

4 Summary and Conclusions 11

Acknowledgements

References

Figures 


\section{Introduction}

Currently, the precipitation hardened CuCrZr alloys are being evaluated for their use in the first wall and divertor components of ITER. In service, both these components will be exposed to an intense flux of fusion (14 MeV) neutrons and at the same time will experience thermo-mechanical stresses. Experimental investigations have demonstrated, however, that the CuCrZr alloy when irradiated with neutrons in the prime aged condition at temperatures below about $200^{\circ} \mathrm{C}$ become harder but looses its ability to work harden and suffers from loss of ductility and plastic instability [1, 2]. Experimental results indicated that this may be due to the fact that the precipitates in this alloy in the prime aged condition were too small in size and thus too weak obstacles to dislocation motion during deformation. It was, therefore, decided to coarsen the precipitate size by annealing after prime ageing heat treatment so that the larger and thereby stronger precipitate may prevent the initiation of plastic flow localization by resisting dislocation motion.

Another reason for investigating the effect of heat treatment was the uncertainty in the temperature at which the copper alloys may be joined to 316 stainless steel while manufacturing the first wall panels. For this reason it was decided to investigate the effect of annealing at different temperatures that may be relevant for the manufacturing of the components. In the following, we describe these two sets of investigations on the effects of heat treatments on the precipitate microstructure (section 3.1). Main results of the post-deformation (after irradiation) microstructure are described in section 3.2. The mechanical properties of the CuCrZr alloy are described in sections 3.2 and 3.4. A brief summary and conclusions are presented in section 4 .

\section{Materials and Experimental Procedure}

The CuCrZr alloy (Cu-0.73\%Cr-0.14\%Zr) supplied by Outokumpu Oyj (Finland) was solution annealed at $960^{\circ} \mathrm{C}$ for $3 \mathrm{~h}$, water quenched and then prime aged (PA) at $460^{\circ} \mathrm{C}$ for $3 \mathrm{~h}$. After prime ageing the specimens were given further heat treatments to modify the precipitate microstructure. In the first series, the prime aged specimens were annealed in vacuum at $600^{\circ} \mathrm{C}$ for 1,2 and $4 \mathrm{~h}$. In the second series a number of prime aged specimens were annealed at 700 and $850^{\circ} \mathrm{C}$ for $4 \mathrm{~h}$. In both series of experiments, the specimens were water quenched after final annealing at various temperatures.

After each heat treatment, specimens were examined in a transmission electron microscope (TEM) in order to determine the effect of various heat treatments on the size and density of precipitates.

A number of tensile and fracture toughness specimens of the CuCrZr alloy in the prime aged condition and the specimens further heat treated at $600^{\circ} \mathrm{C}$ for 1 and 4 hours were irradiated with fission neutrons in the BR-2 reactor at Mol (Belgium) at 60 and $300^{\circ} \mathrm{C}$ to a displacement dose level of $\sim 0.3 \mathrm{dpa}$ (displacement per atom). The damage rate during irradiation was $\sim 6 \times 10^{-8} \mathrm{dpa} \mathrm{s}^{-1}$. 
The prime aged and various heat treated specimens were tensile tested at 50 and $300^{\circ} \mathrm{C}$. All tests were carried out in vacuum $\left(<10^{-4}\right.$ torr) at a strain rate of $1.2 \times 10^{-3} \mathrm{~s}^{-1}$. The single edge notched bend SEN(B) fracture toughness specimens of dimensions $3 \times 4 \times 27$ $\mathrm{mm}$ were used in the fracture resistance testing. The initial notch and the $20 \%$ side grooves were machined by applying the electric wire discharge machining. The applied prefatigued crack length to specimen width ratio $(\mathrm{a} / \mathrm{W})$ was about 0.5 . Fracture resistance curves were determined using the displacement controlled three point bend test method with a constant displacement rate of $1.5 \times 10^{-2} \mathrm{~mm} / \mathrm{min}$. Fracture resistance testing at elevated temperatures were carried out in a silicon oil bath. Load, displacement and crack length measured using the DC-PD method were recorded during the testing and the fracture resistance curves were determined following the ASTM E1737-96 standard procedure.

The prime aged as well as specimens heat treated at $600^{\circ} \mathrm{C}$ for 1 and $4 \mathrm{~h}$ and subsequently irradiated at 60 and $300^{\circ} \mathrm{C}$ were also tensile tested in the post-irradiation condition. All tests were carried out in vacuum $\left(<10^{-4}\right.$ torr $)$ at a strain rate of $1.2 \times 10^{-3}$ $\mathrm{s}^{-1}$. The specimens irradiated at $60^{\circ} \mathrm{C}$ were tensile tested at 22 and $60^{\circ} \mathrm{C}$ whereas those irradiated at $300^{\circ} \mathrm{C}$ were tensile tested at $300^{\circ} \mathrm{C}$. Fracture toughness tests were carried out at 20 and $300^{\circ} \mathrm{C}$.

Characterization of the microstructures of CuCrZr specimens after different heat treatments was performed using a JEOL-2000FX transmission electron microscope. 3 $\mathrm{mm}$ diameter discs were punched out from the heat treated samples and were mechanically polished down to a thickness of $\sim 120 \mu \mathrm{m}$. Thin foils were prepared from these discs by electro polishing in a $25 \%$ perchloric acid, $25 \%$ ethanol and 50\% water electrolyte at room temperature $\left(\sim 22^{\circ} \mathrm{C}\right), 9$ volts and $\sim 20 \mathrm{~mA}$ for about $15 \mathrm{~s}$.

\section{Results}

\subsection{Microstructure}

After each heat treatment, specimens were examined in a transmission electron microscope (TEM) and precipitate size and density were determined. As expected, heat treatments after prime ageing (PA) led to significant coarsening of the prime aged precipitate microstructure. Figure 1 shows the size distributions of precipitates determined after annealing at $600^{\circ} \mathrm{C}$ for 1,2 and 4 hours. For comparison, the size distribution for the specimen in the prime aged condition is also shown in Figure 1. The average precipitate size and density for various heat treatments are quoted in Table 1.

Figure 2 shows the size distribution for annealing at $700^{\circ} \mathrm{C}$ for 4 hours. The annealing at $850^{\circ} \mathrm{C}$ for 4 hours led to very low density of rather large and heterogeneously distributed precipitates and therefore no quantitative measurements were made. Examples of precipitate microstructure after prime ageing and annealing at $600^{\circ} \mathrm{C}$ for 4 hours and at $700^{\circ} \mathrm{C}$ for 4 hours are shown in Figure 3. 
Table 1. The average precipitate size and density in CuCrZr alloy after different heat treatments

\begin{tabular}{|l|c|c|}
\hline Heat Treatment & $\begin{array}{c}\text { Precipitate Size } \\
(\mathrm{nm})\end{array}$ & $\begin{array}{c}\text { Precipitate Density } \\
\left(\mathrm{m}^{-3}\right)\end{array}$ \\
\hline $\mathrm{PA}^{*}$ & 2.2 & $2.6 \times 10^{23}$ \\
$\mathrm{PA}+600^{\circ} \mathrm{C} / 1 \mathrm{~h}$ & 8.7 & $1.7 \times 10^{22}$ \\
“ $\quad / 2 \mathrm{~h}$ & 9.4 & $1.8 \times 10^{22}$ \\
“ $\quad / 4 \mathrm{~h}$ & 21.3 & $1.5 \times 10^{21}$ \\
$\mathrm{PA}+700^{\circ} \mathrm{C} / 4 \mathrm{~h}$ & 46.4 & $7.0 \times 10^{20}$ \\
$\mathrm{PA}+850^{\circ} \mathrm{C} / 4 \mathrm{~h}$ & $\mathrm{NA}^{+}$ & $\mathrm{NA}^{+}$ \\
\hline
\end{tabular}

*Prime Aged

${ }^{+}$Precipitate density was too low and too heterogeneous for quantitative measurements

\subsection{Tensile properties}

The prime aged (PA) and the overaged specimens were tensile tested at 50 and $300^{\circ} \mathrm{C}$. All tests were carried out in vacuum $\left(<10^{-4}\right.$ torr $)$ and at a strain rate of $1.2 \times 10^{-3} \mathrm{~s}^{-1}$. The engineering stress-strain curves for the PA specimen and specimens heat treated at $600^{\circ} \mathrm{C}$ for 1 and 4 hours tested at 50 and $300^{\circ} \mathrm{C}$ are shown in Figure 4 . Figure 5 shows the stress strain curves for the specimens annealed for 4 hours at 600,700 and $850^{\circ} \mathrm{C}$ and tested at 50 and $300^{\circ} \mathrm{C}$. For comparison, the stress-strain curves for the prime aged specimens are also shown.

The results shown in Figs. 4 and 5 clearly show that the tensile strength decreases both at 50 and $300^{\circ} \mathrm{C}$ with increasing annealing time at a given annealing temperature (e.g. $600^{\circ} \mathrm{C}$ ) and with increasing annealing temperature for a given annealing time (i.e. 4 hours). This is consistent with the precipitate microstructure (Table 1) in that as precipitate microstructure coarsens with increasing annealing time and temperature, the tensile strength decreases accordingly.

A number of tensile specimens of $\mathrm{CuCrZr}$ alloy in the prime aged condition and specimens heat treated at $600^{\circ} \mathrm{C}$ for 1 and 4 hours were irradiated at 60 and $300^{\circ} \mathrm{C}$ to a displacement dose level of $\sim 0.3 \mathrm{dpa}$. The specimens irradiated at $60^{\circ} \mathrm{C}$ were tensile tested (in vacuum) at a strain rate of $1.2 \times 10^{-3} \mathrm{~s}^{-1}$ at 22 and $60^{\circ} \mathrm{C}$. The specimens irradiated at $300^{\circ} \mathrm{C}$ to a dose level of 0.3 dpa were tensile tested at $300^{\circ} \mathrm{C}$ (in vacuum) and also at a strain rate of $1.2 \times 10^{-3} \mathrm{~s}^{-1}$. The engineering stress-strain curves for specimens irradiated at 60 and $300^{\circ} \mathrm{C}$ are shown in Figs. 6 and 7, respectively. For comparison, stress-strain curves for OFHC-copper irradiated and tested under the same condition as the CuCrZr alloy are also shown in Fig. 6 and 7.

As can be seen in Fig. 6, irradiation at $60^{\circ} \mathrm{C}$ to a dose level of $\sim 0.3$ dpa caused a moderate amount of increase in the yield strength of the prime-aged as well as overaged alloys at $600^{\circ} \mathrm{C}$ for 1 and 4 hours. The increase in the yield strength is, however, accompanied by a substantial decrease in the ductility of the irradiated CuCrZr alloy with different pre-irradiation heat treatments. What is most significant and important 
from the technological point of view is the observation that the irradiation at $60^{\circ} \mathrm{C}$ to 0.3 dpa did not cause any noticeable yield drop and plastic instability. It should be pointed out, however, that although the overageing heat treatments have eliminated the technological problem of plastic instability at the very beginning of the plastic deformation, the irradiated CuCrZr alloy still suffers from the lack of work hardening and the reduction in the ductility. Some further adjustment of the pre-irradiation microstructure by thermo-mechanical treatments, for instance, may be necessary to address these problems.

The results of post-irradiation tensile tests on specimens irradiated and tested at $300^{\circ} \mathrm{C}$ (Fig. 7) demonstrate that the CuCrZr alloy both in the prime aged and overaged conditions becomes noticeably softer due to irradiation at $300^{\circ} \mathrm{C}$ to $0.3 \mathrm{dpa}$.

The measured values of $0.2 \%$ engineering stress $\left(\sigma_{0.2}\right)$, this ultimate tensile stress $\left(\sigma_{\max }\right)$ and the uniform and total elongations $\left(\varepsilon_{\mathrm{u}}\right.$ and $\left.\varepsilon_{\mathrm{t}}\right)$ are quoted in Table 2.

Table 2. Effect of heat treatments on tensile properties of CuCrZr alloy before and after irradiation at 60 and $300^{\circ} \mathrm{C}$ to $0.3 \mathrm{dpa}$

\begin{tabular}{|c|c|c|c|c|c|c|c|c|}
\hline $\begin{array}{l}\text { Test } \\
\text { No. }\end{array}$ & $\begin{array}{l}\text { Heat } \\
\text { Treatment }\end{array}$ & $\begin{array}{l}\text { Irr. } \\
\text { Temp. } \\
\left({ }^{\circ} \mathrm{C}\right)\end{array}$ & $\begin{array}{l}\text { Dose } \\
\text { (dpa) }\end{array}$ & $\begin{array}{l}\text { Test } \\
\text { Temp. } \\
\left({ }^{\circ} \mathrm{C}\right)\end{array}$ & $\begin{array}{l}\sigma_{0.2} \\
(\mathrm{Mpa})\end{array}$ & $\begin{array}{l}\sigma_{\max } \\
(\mathrm{Mpa})\end{array}$ & $\begin{array}{l}\varepsilon_{\mathrm{u}} \\
(\%)\end{array}$ & $\begin{array}{l}\varepsilon_{\mathrm{t}} \\
(\%)\end{array}$ \\
\hline 1225 & PA & - & - & 50 & 290.0 & 398.0 & 24.0 & 28.0 \\
\hline 1226 & $"$ & - & - & 50 & 295.0 & 416.0 & 22.0 & 30.0 \\
\hline 1382 & $"$ & - & - & 60 & 280.0 & 373.1 & 21.3 & 25.4 \\
\hline 1384 & “ & - & - & 60 & 260.0 & 364.0 & 20.0 & 24.0 \\
\hline 1217 & HT1 & - & - & 50 & 200.0 & 318.0 & 26.0 & 30.0 \\
\hline 1211 & HT2 & - & - & “ & 175.0 & 289.0 & 24.0 & 32.0 \\
\hline 1218 & “ & - & - & “ & 165.0 & 307.0 & 34.0 & 41.0 \\
\hline 1219 & PA & - & - & 300 & 240.0 & 304.0 & 18.0 & 27.0 \\
\hline 1220 & “ & - & - & “ & 250.0 & 328.0 & 17.0 & 23.0 \\
\hline 1385 & “ & - & - & “ & 244.0 & 308.0 & 15.0 & 19.0 \\
\hline 1221 & HT1 & - & - & 300 & 180.0 & 255.0 & 19.0 & 24.0 \\
\hline 1222 & “ & - & - & “ & 150.0 & 227.0 & 17.0 & 21.0 \\
\hline 1223 & HT2 & - & - & 300 & 135.0 & 218.0 & 22.0 & 28.0 \\
\hline 1224 & “ & - & - & “ & 120.0 & 201.0 & 25.0 & 36.0 \\
\hline 1360 & PA & 60 & 0.3 & 60 & 435.0 & 436.0 & 2.0 & 6.0 \\
\hline 1353 & $"$ & “ & “ & 22 & 450.0 & 458.6 & 1.7 & 6.8 \\
\hline 1354 & HT1 & “ & “ & 22 & 410.0 & 422.2 & 1.8 & 9.6 \\
\hline 1358 & $”$ & “ & “ & 60 & 397.0 & 397.0 & 2.0 & 15.0 \\
\hline 1355 & HT2 & “ & “ & 22 & 360.0 & 363.0 & 1.4 & 9.7 \\
\hline
\end{tabular}




\begin{tabular}{|c|c|c|c|c|c|c|c|c|}
\hline 1359 & $”$ & “ & “ & 60 & 372.0 & 372.0 & 1.0 & 7.0 \\
1386 & PA & 300 & “ & 300 & 210.0 & 268.0 & 10.0 & 12.0 \\
1577 & “ & “ & “ & “ & 190.0 & 245.0 & 6.0 & 8.0 \\
1387 & HT1 & “ & “ & 300 & - & 209.0 & 14.0 & 18.0 \\
1576 & “ & “ & “ & “ & 134.0 & 192.0 & 9.0 & 12.0 \\
1388 & HT2 & “ & “ & 300 & - & 193.0 & 21.0 & 27.0 \\
1389 & “ & “ & “ & “ & 119.0 & 188.0 & 20.0 & 26.0 \\
\hline
\end{tabular}

PA: Prime aged.

HT1: $\mathrm{PA}+600^{\circ} \mathrm{C} / 1 \mathrm{~h} ; \quad \mathrm{HT} 2: \quad \mathrm{PA}+600^{\circ} \mathrm{C} / 4 \mathrm{~h}$.

\subsection{Post-deformation microstructure}

Microstructures of the $\mathrm{CuCrZr}$ alloy with different heat treatments and irradiated at 60 and $300^{\circ} \mathrm{C}$ to 0.3 dpa were investigated using transmission electron microscopy in the asirradiated as well as in the irradiated and deformed conditions.

Even though none of the irradiated specimens exhibited any noticeable yield drop and plastic instability, yet the evidence of plastic flow localization in the form of cleared channels was found in all of the irradiated and deformed specimens (see Fig. 8). The localized deformation in the cleared channels may be responsible for the lack of work hardening as well as the reduction in the ductility of specimens irradiated at $60^{\circ} \mathrm{C}$ to 0.3 dpa.

\subsection{Fracture toughness behaviour}

The data measured during fracture toughness testing of three point bend specimens, e.g., load, load line displacement and potential drop values are presented in normalised form in order to make it more informative to compare the results of individual tests and material conditions. The normalised load-displacement curves give qualitative information on the effects of heat treatment, test temperature etc. on fracture behaviour of three point bend specimens.

Typical normalised load-displacement curves for CuCrZr alloy in the unirradiated and neutron irradiated conditions are shown in Figure 9. The three point bend loaddisplacement curves show a general trend which is similar to that exhibited by the tensile stress-strain curves, i.e., decrease in the strength level due to overaging compared to that in prime aged condition. At the ambient temperature the unirradiated CuCrZr alloy shows relatively flat normalised load-displacement curve without any clear maximum indicating an extensive plastic deformation and crack tip blunting without clear crack extension, i.e., the CuCrZr base alloy has relatively high fracture toughness. In the overaged conditions the normalised load-displacement curves are at lower load levels but the curves have a similar general form to that in the prime aged condition. In the neutron irradiated condition the load levels of the normalised load-displacement curves increase and the general form is more flat and goes through a maximum when compared to that in 
the unirradiated condition at ambient temperature. This indicates that the CuCrZr alloy had relatively high toughness also after irradiation at the ambient temperature. The most pronounced change is observed when the CuCrZr alloy is irradiated and tested at $300^{\circ} \mathrm{C}$, i.e., in both prime aged and overaged conditions the normalised load-displacement curves show a clear maximum indicating relatively low fracture toughness.

Fracture resistance curves of CuCrZr alloy in the unirradiated and the neutron irradiated conditions are shown in Figure 10. In the unirradiated condition clear stable crack growth was observed only in the prime aged condition at $200^{\circ} \mathrm{C}$ where the initiation fracture toughness $\mathrm{J}_{\mathrm{Q}}$ value was about $180 \mathrm{kJm}^{-2}$. In all the other condition strong crack tip blunting was observed and in those cases the maximum J-integral values are reported in Table 3. In the irradiated condition crack tip blunting without any stable crack growth was also observed when irradiation and fracture toughness tests were carried out at the ambient temperature. Relatively low initiation fracture toughness values of about 33 $\mathrm{kJm}^{-2}$ and $82 \mathrm{kJm}^{-2}$ were observed in the prime aged and the overaged conditions, respectively, when irradiated and fracture toughness tested at $300^{\circ} \mathrm{C}$. It is noted that only those $\mathrm{J}_{\mathrm{Q}}$ values for the prime aged $\mathrm{CuCrZr}$ alloy which were irradiated and tested at $300^{\circ} \mathrm{C}$ are valid according to limitations $\left(\mathrm{J}_{\max }=\mathrm{b}_{0} \sigma_{\mathrm{y}} / 20\right.$, where $\mathrm{b}_{0}$ is remaining ligament and $\sigma_{\mathrm{y}}$ is flow stress) set for specimen dimensions. Limiting values of $\mathrm{J}_{\max }$ for the prime aged and overaged conditions are about 90 and $83 \mathrm{kJm}^{-2}$ at the ambient temperature and 45 and $35 \mathrm{kJm}^{-2}$ at $300^{\circ} \mathrm{C}$, respectively.

Table 3. Effect of heat treatments on initiation fracture toughness of $\mathrm{CuCrZr}$ alloy before and after irradiation.

\begin{tabular}{|l|l|l|l|l|l|l|}
\hline Test No. & $\begin{array}{l}\text { Heat } \\
\text { treatment }\end{array}$ & $\begin{array}{l}\text { Irr. temp. } \\
\left({ }^{\circ} \mathrm{C}\right)\end{array}$ & $\begin{array}{l}\text { Dose } \\
(\mathrm{dpa})\end{array}$ & $\begin{array}{l}\text { Test temp. } \\
\left({ }^{\circ} \mathrm{C}\right)\end{array}$ & $\begin{array}{l}\mathrm{J}_{\mathrm{Q}} \\
\left(\mathrm{kJm}^{-2}\right)\end{array}$ & \\
\hline M2562 & PA & - & - & 100 & 230 & $*$ \\
\hline M2585 & PA & - & - & 200 & 183 & \\
\hline M2565 & HT1 & - & - & 100 & 224 & $*$ \\
\hline M2586 & HT1 & - & - & 200 & 285 & $*$ \\
\hline M1993 & HT2 & - & - & 20 & 220 & $*$ \\
\hline M2566 & HT2 & - & - & 100 & 200 & $*$ \\
\hline M2873 & HT2 & - & - & 200 & 154 & $*$ \\
\hline M2804 & PA & 60 & 0.3 & 20 & 301 & $*$ \\
\hline M2805 & PA & 60 & 0.3 & 20 & 400 & $*$ \\
\hline M2807 & PA & 60 & 0.3 & 20 & 416 & $*$ \\
\hline M2806 & HT1 & 60 & 0.3 & 20 & 342 & $*$ \\
\hline M2808 & HT1 & 60 & 0.3 & 20 & 304 & $*$ \\
\hline M2809 & HT1 & 60 & 0.3 & 20 & 348 & $*$ \\
\hline
\end{tabular}




\begin{tabular}{|l|l|l|l|l|l|l|}
\hline M2821 & PA & 300 & 0.3 & 300 & 26 & \\
\hline M2822 & PA & 300 & 0.3 & 300 & 20 & \\
\hline M2859 & PA & 300 & 0.3 & 300 & 25 & \\
\hline M2858 & PA & 300 & 0.3 & 300 & 38 & \\
\hline M2857 & PA & 300 & 0.3 & 300 & 58 & \\
\hline M2860 & HT1 & 300 & 0.3 & 300 & 72 & \\
\hline M2861 & HT1 & 300 & 0.3 & 300 & 84 & \\
\hline M2862 & HT1 & 300 & 0.3 & 300 & 89 & \\
\hline
\end{tabular}

PA: Prime aged.

HT1: PA $+600^{\circ} \mathrm{C} / 1 \mathrm{~h} ; \quad \mathrm{HT} 2: \quad \mathrm{PA}+600^{\circ} \mathrm{C} / 4 \mathrm{~h}$.

* crack tip blunting

\section{Summary and conclusions}

The changes in the precipitate microstructure of the CuCrZr alloy due to different heat treatments were quantitatively characterized using transmission electron microscopy. Results showed that the precipitate density decreases very rapidly with increasing overageing time at $600^{\circ} \mathrm{C}$. For instance, the overageing for 2 and 4 hours led to a reduction in precipitate density by a factor of about 10 and 200, respectively, compared to the density in the prime aged condition. The overageing at $850^{\circ} \mathrm{C}$ for 4 hours caused almost a complete resolution of the precipitates. The reduction in the precipitate density must be responsible for a significant decrease in the tensile strength of the alloy due to overageing. On the other hand overaging did not have any significant effects on fracture toughness properties.

The irradiation at $60^{\circ} \mathrm{C}$ to a dose level of $\sim 0.3$ dpa caused some noticeable amount of hardening both in the prime aged and overaged specimens. The ductility, on the other hand, remained significantly reduced. The irradiation did not caused any noticeable changes in fracture toughness properties at ambient temperature. The irradiation at $300^{\circ} \mathrm{C}$ to a dose level of $\sim 0.3$ dpa did not cause any hardening. However, initiation fracture toughness was significantly reduced in both prime aged and overaged conditions at $300^{\circ} \mathrm{C}$.

The most significant effect of the overageing heat treatments was that the heat treatment eliminated the problem of yield drop and plastic instability. However, the overageing heat treatments neither restored the work hardening ability nor the ductility of the alloy. The post-deformation microstructure of the irradiated alloy suggests that even the overaged alloy suffers from the problem of flow localization in the form of cleared channels and this may by responsible for the lack of work hardening as well as the reduction in ductility due to irradiation. 


\section{Acknowledgements}

The work reported here was partly funded by the European Fusion Technology Programme.

\section{References}

1. B.N. Singh, D.J. Edwards and P. Toft, Effects of neutron irradiation on mechanical properties and microstructures of dispersion and precipitation hardened copper alloys, J. Nucl. Mater. 238 (1996) 244-259.

2. D.J. Edwards, B.N. Singh, P. Toft and M. Eldrup, The effect of bonding and bakeout thermal cycles on the properties of copper alloys irradiated at $100^{\circ} \mathrm{C}, \mathrm{J}$. Nucl. Mater. $\underline{258}-\underline{263}$ (1998) 978-984. 


\section{Figures}

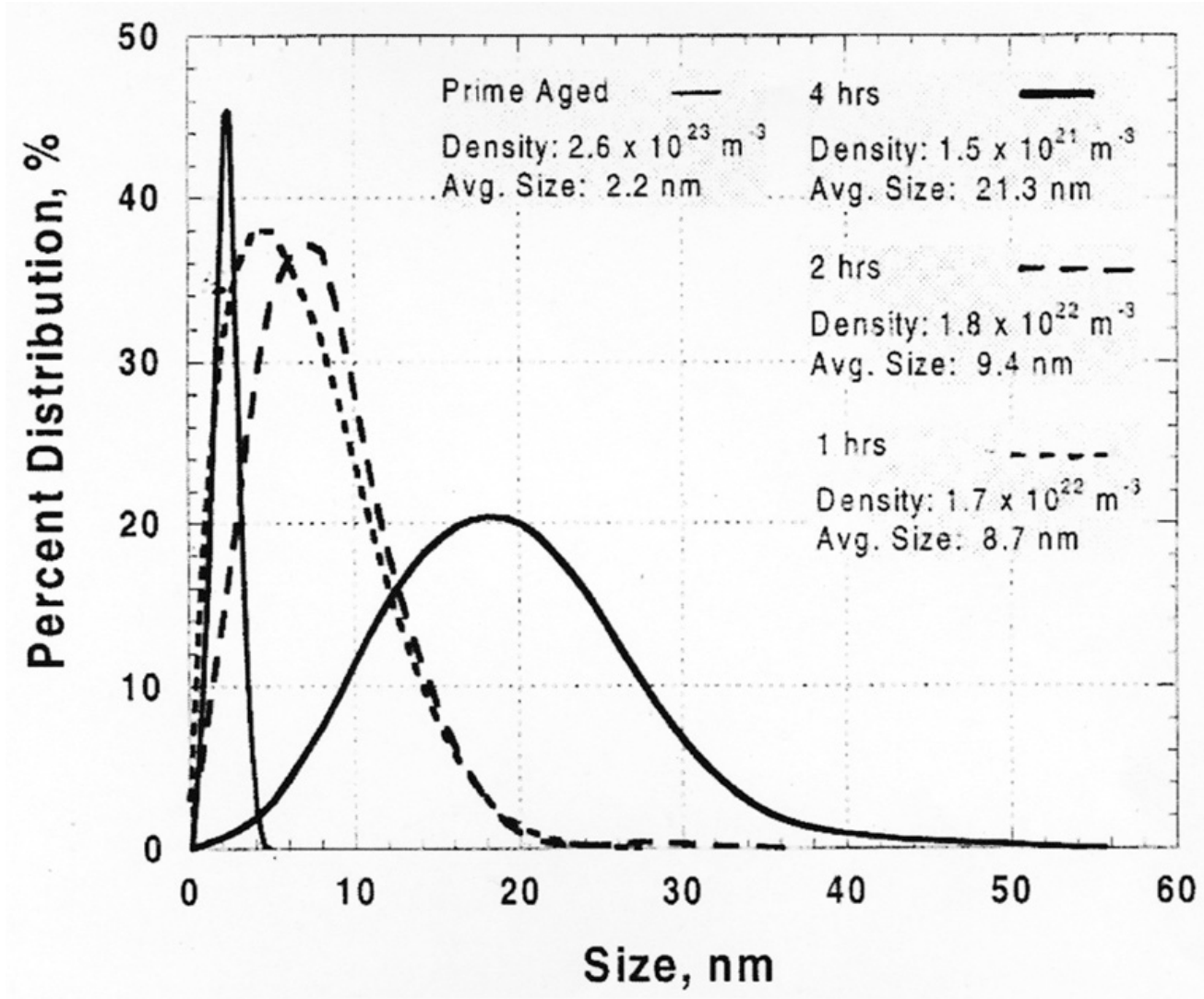

Figure 1. Precipitate size distribution in the unirradiated $\mathrm{CuCrZr}$ alloy in the prime aged and heat treated (after prime ageing) specimens at $600^{\circ} \mathrm{C}$ for 1,2 and 4 hours. 


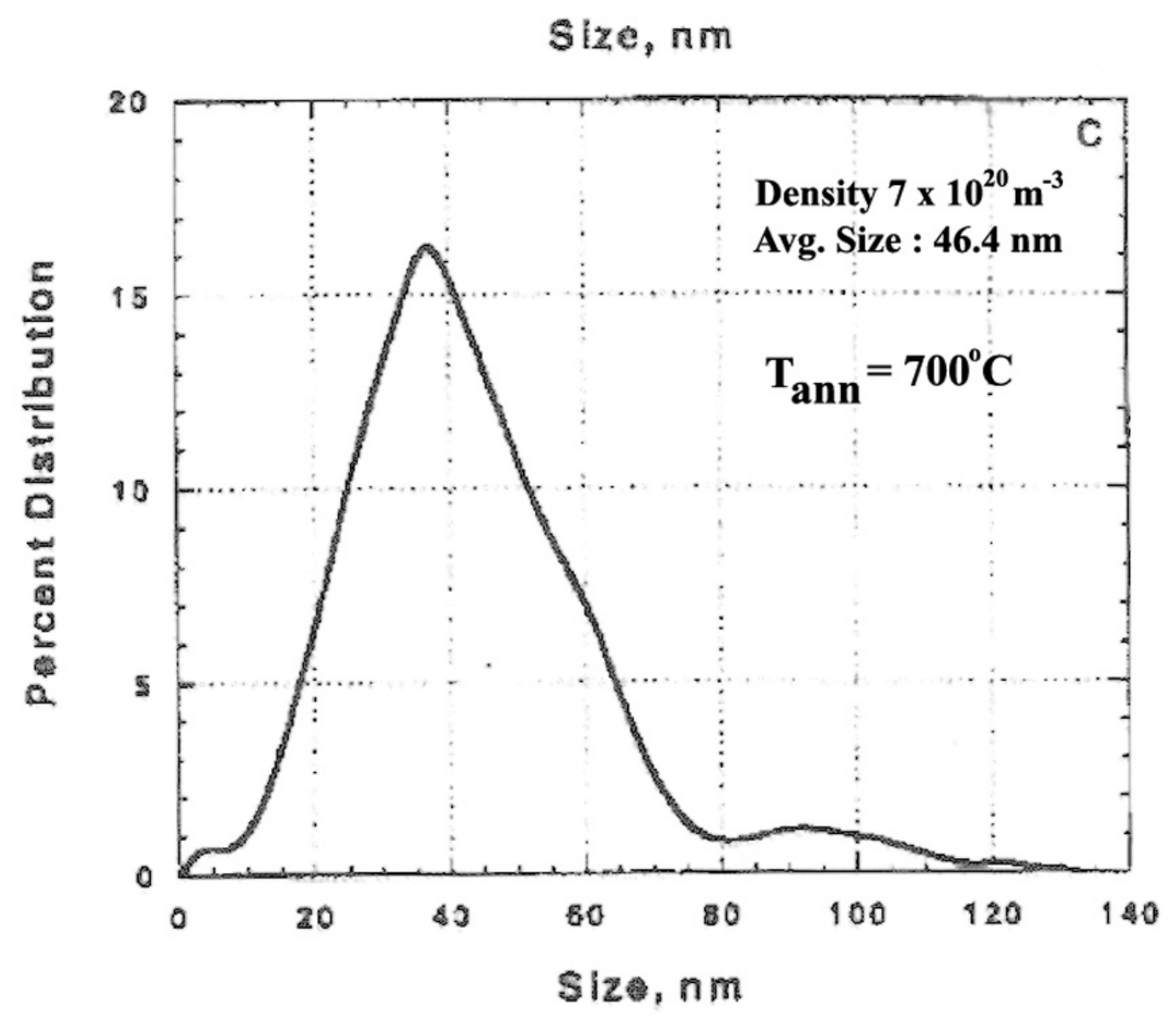

Figure 2. Precipitate size distribution in the unirradiated $\mathrm{CuCrZr}$ alloy overaged (after prime ageing) at $700^{\circ} \mathrm{C}$ for 4 hours. 


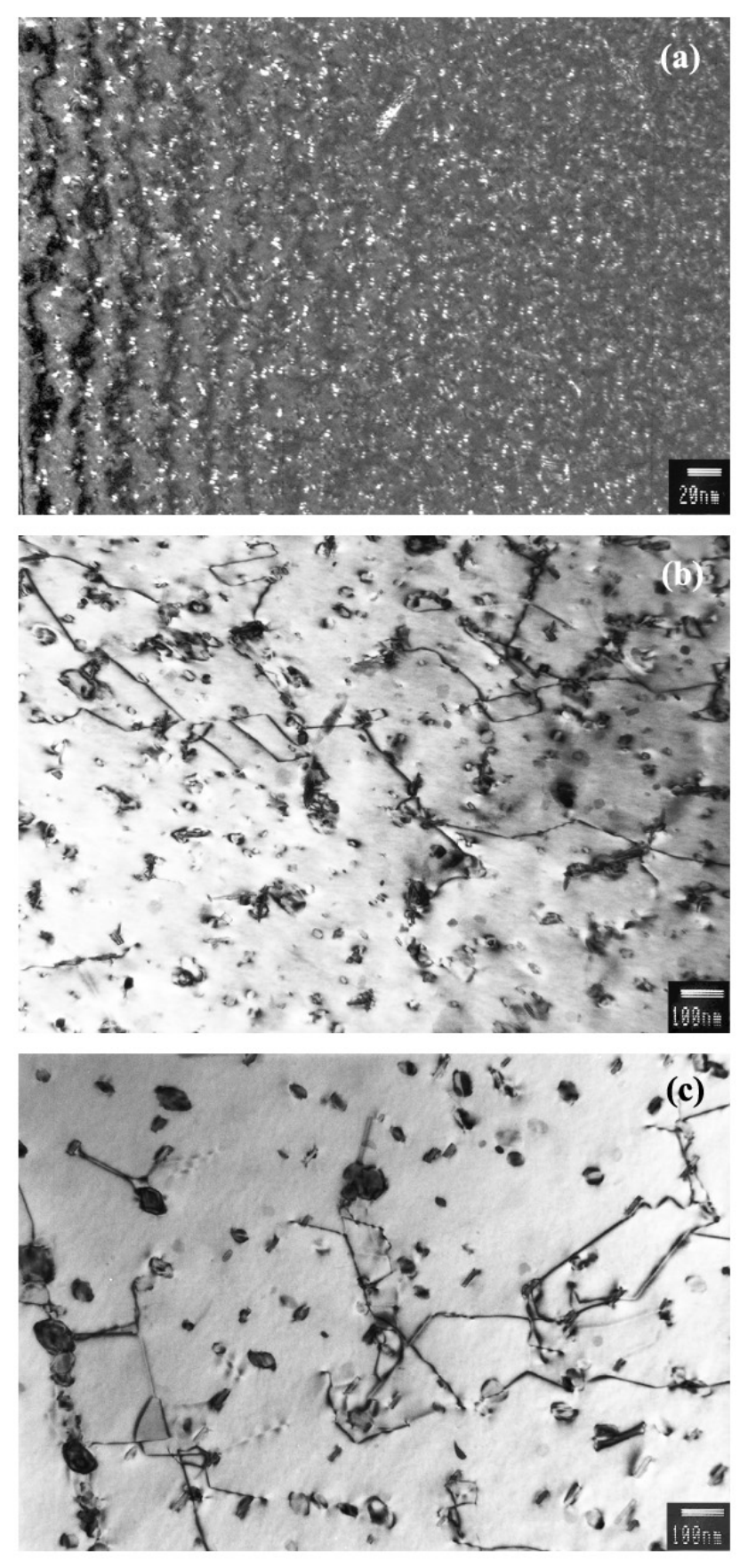

Figure 3. Examples of precipitate microstructure after (a) prime ageing, (b) annealing at $600^{\circ} \mathrm{C}$ for 4 hours and (c) annealing at $700^{\circ} \mathrm{C}$ for 4 hours. 

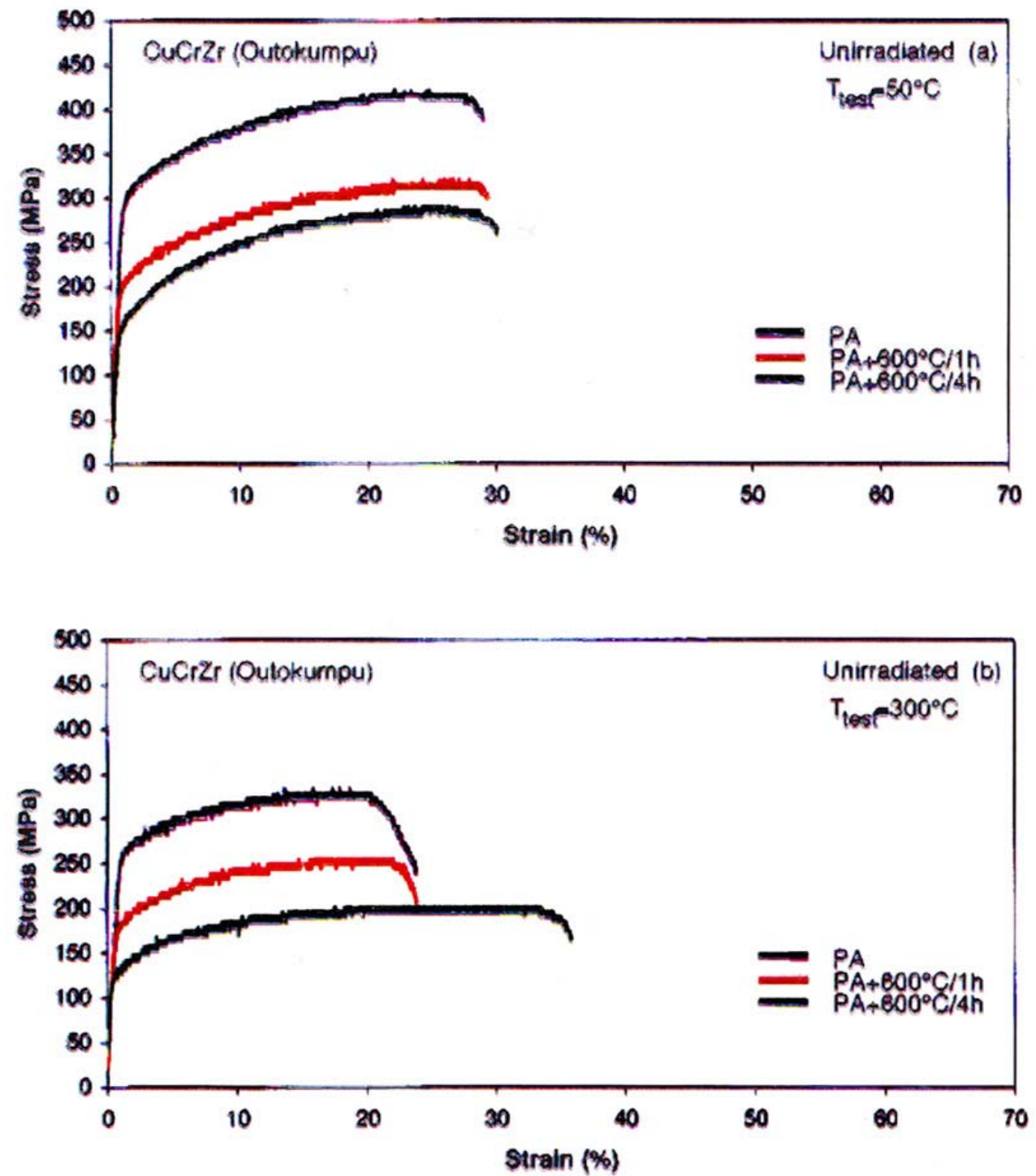

Figure 4. Stress-strain curves for $\mathrm{CuCrZr}$ alloy in the prime-aged condition and after annealing at $600^{\circ} \mathrm{C}$ for 1 and 4 hours and tensile tested at (a) $50^{\circ} \mathrm{C}$ and (b) $300^{\circ} \mathrm{C}$. 

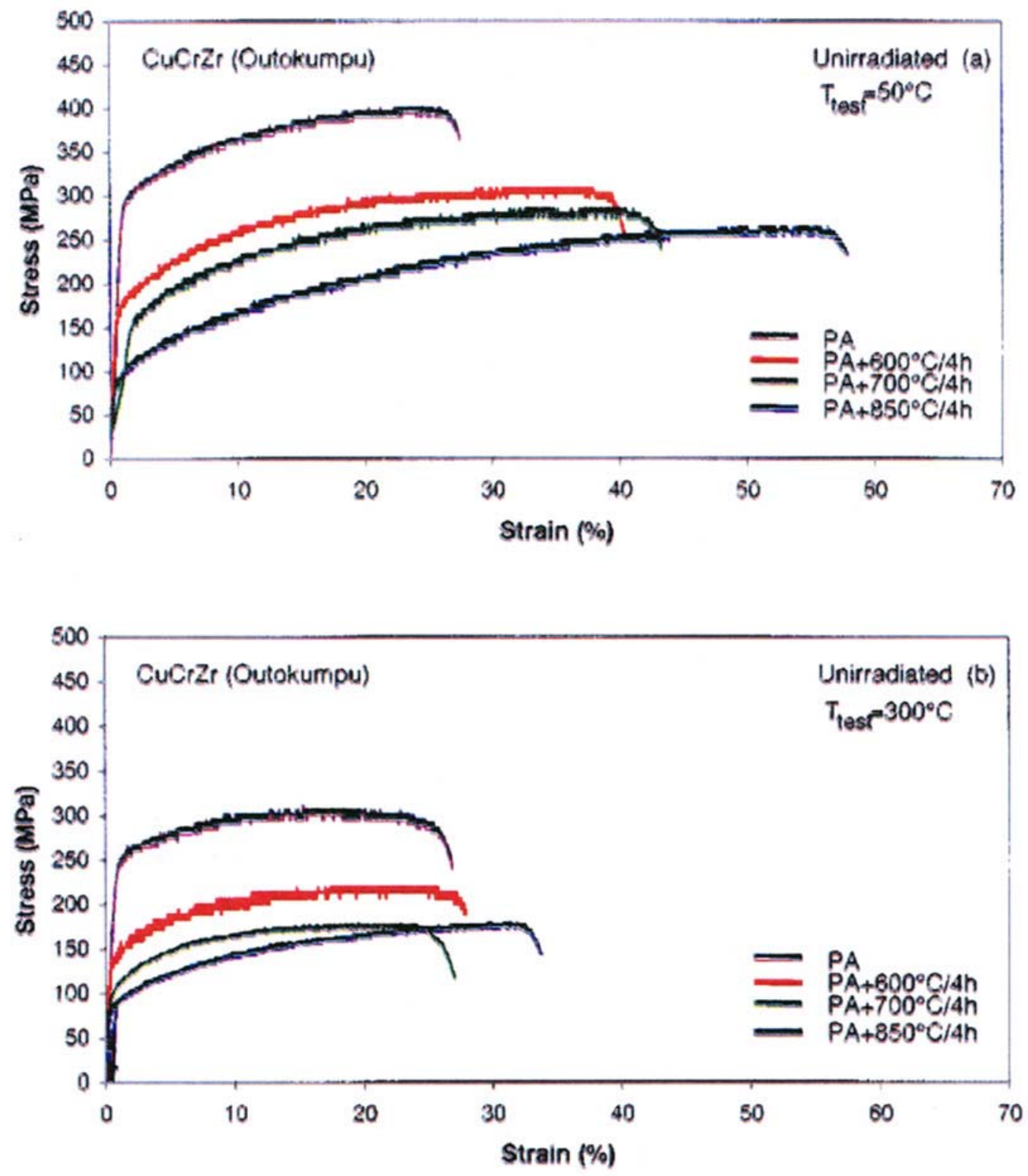

Figure 5. Stress-strain curves for CuCrZr alloy heat treated (after prime ageing) at 600, 700 and $850^{\circ} \mathrm{C}$ for 4 hours and subsequently tensile tested at (a) $50^{\circ} \mathrm{C}$ and (b) $300^{\circ} \mathrm{C}$. 

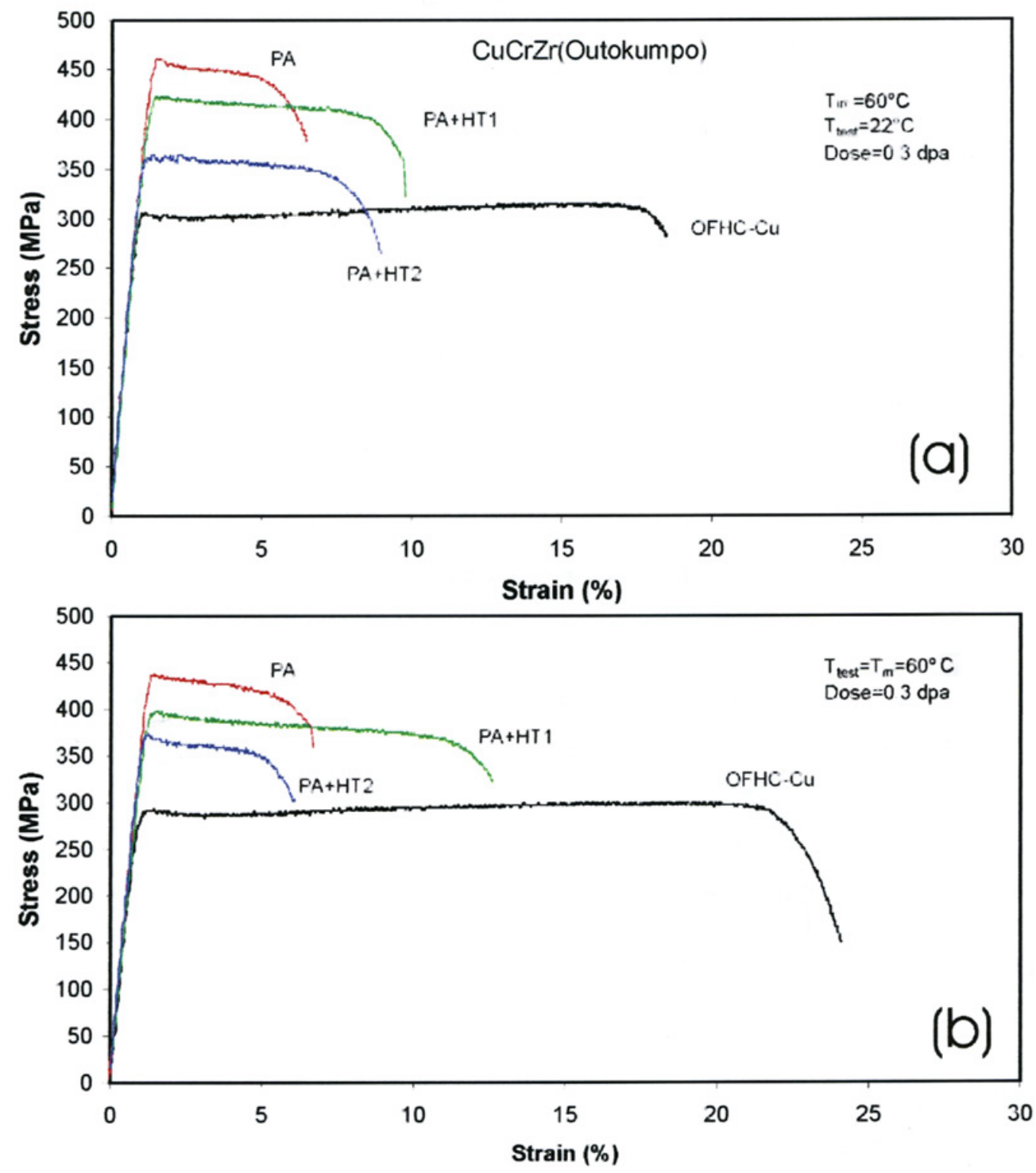

Figure 6. Stress-strain curves for CuCrZr alloy irradiated at $60^{\circ} \mathrm{C}$ to a dose level of $\sim 0.3$ dpa in the prime aged and overaged (at $600^{\circ} \mathrm{C}$ for $1 \mathrm{~h}(\mathrm{PA}+\mathrm{HT} 1)$ and $4 \mathrm{~h}(\mathrm{PA}+\mathrm{HT} 2)$ ) conditions and tensile tested at (a) $22^{\circ} \mathrm{C}$ and (b) $60^{\circ} \mathrm{C}$. 


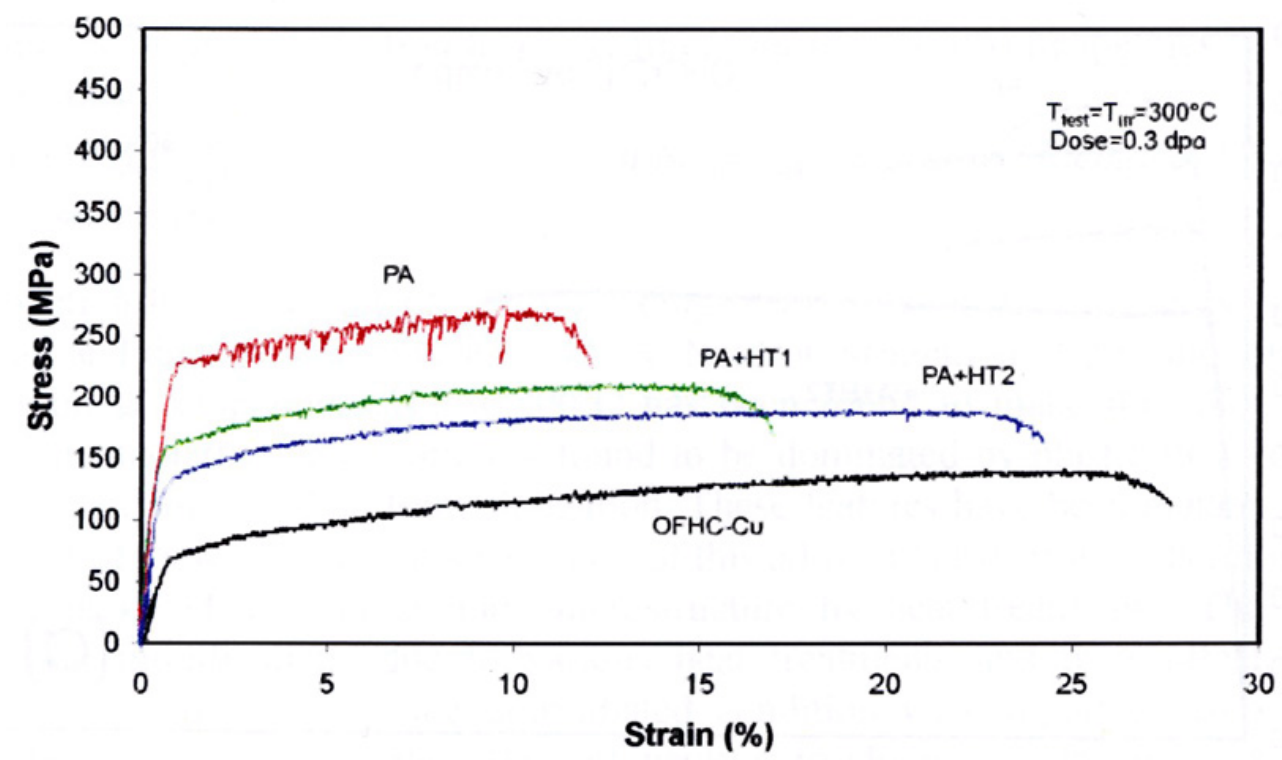

Figure 7. Same as Figure 6 but irradiated and tensile tested at $300^{\circ} \mathrm{C}$. 

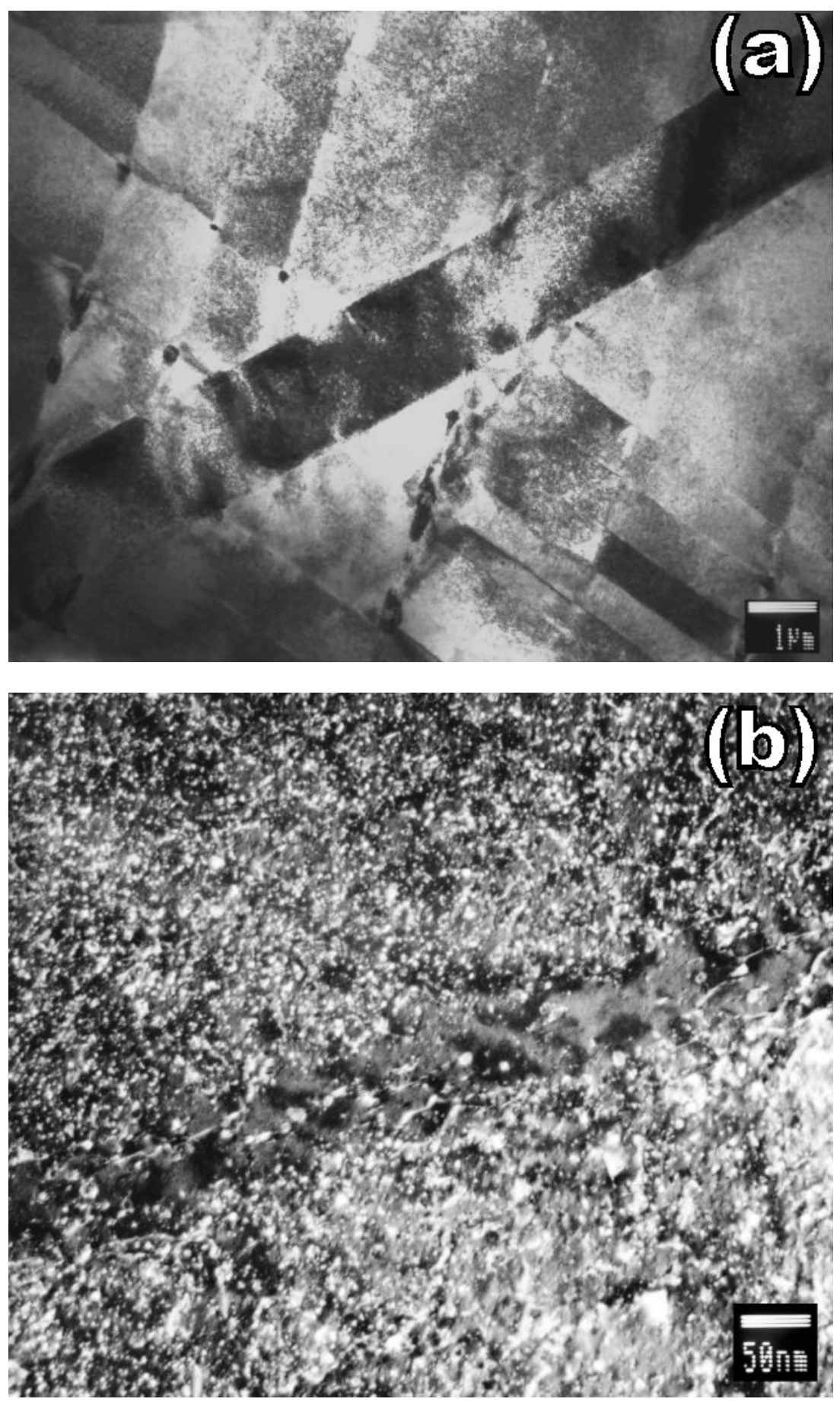

Figure 8. (a,b) 

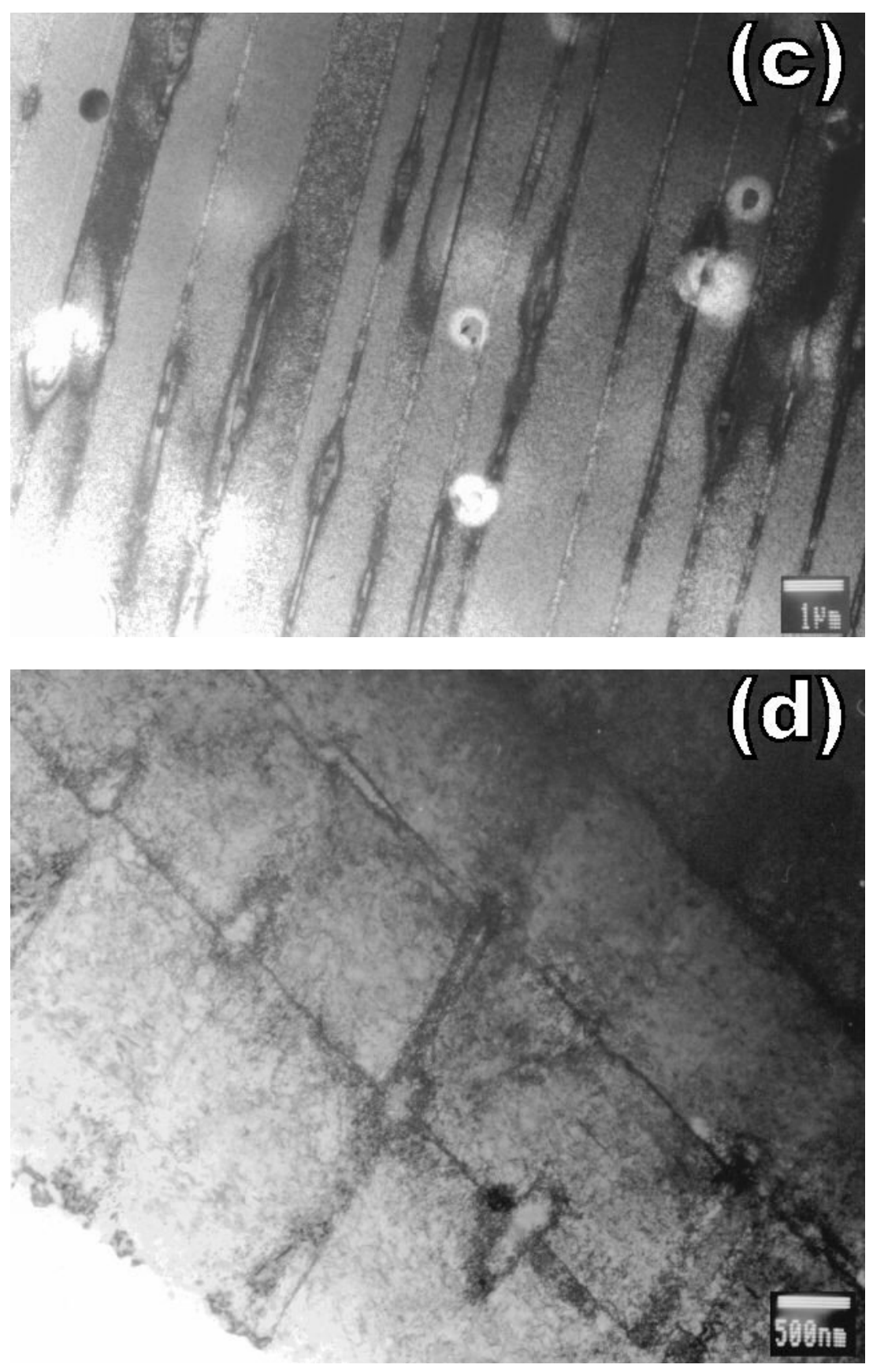

Figure 8. Examples of cleared channel formation in specimens irradiated at $60^{\circ} \mathrm{C}$ to $\sim 0.3$ dpa and deformed at $60^{\circ} \mathrm{C}$ : (a) prime aged, (b) overaged at $600^{\circ} \mathrm{C}$ for $1 \mathrm{~h}$ and (c,d) overaged at $600^{\circ} \mathrm{C}$ for 4 hours. 

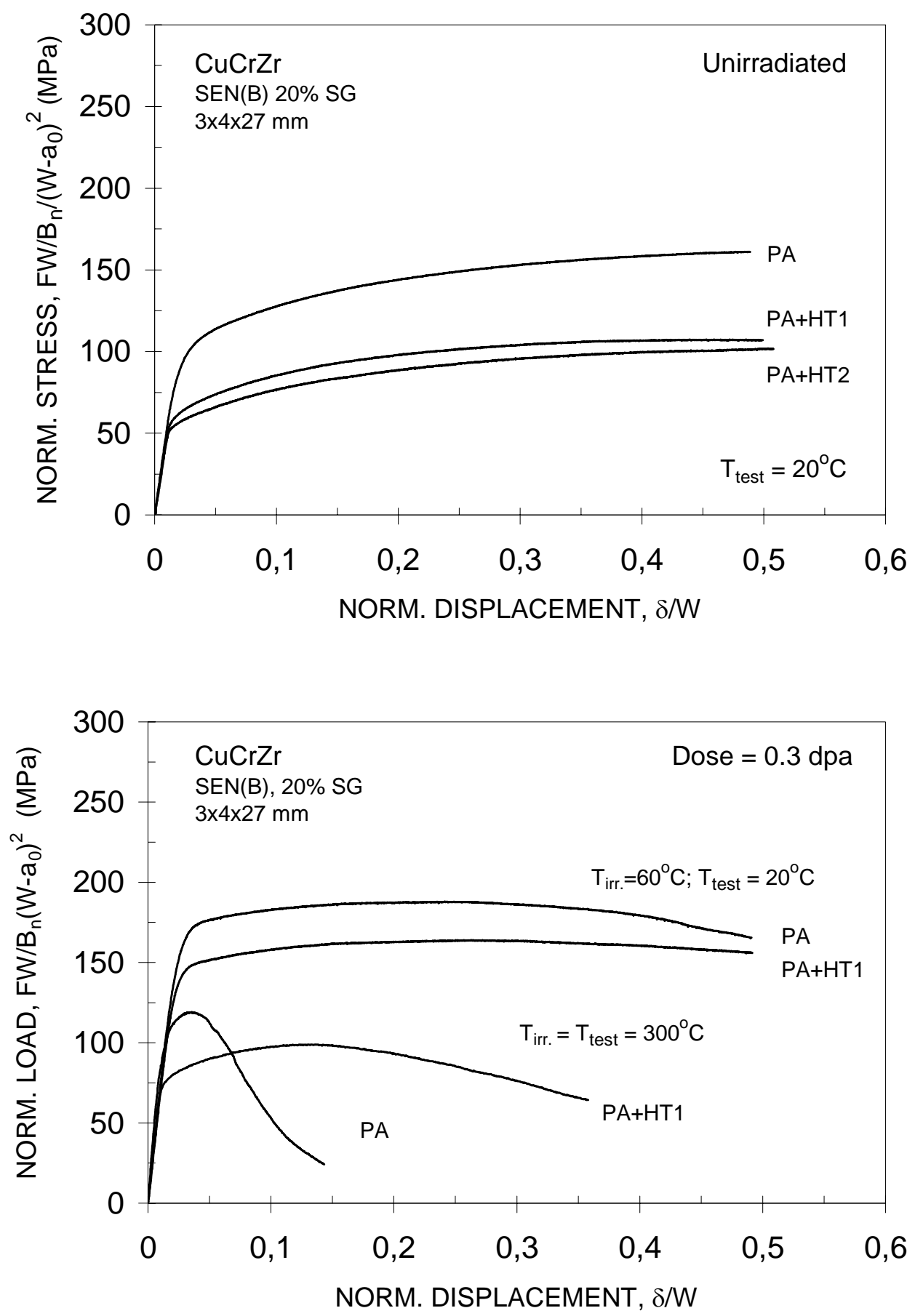

Figure 9. Normalised load-displacement curves for CuCrZr alloy (a) unirradiated in the prime aged and overaged (at $600^{\circ} \mathrm{C}$ for $1 \mathrm{~h}(\mathrm{PA}+\mathrm{HT} 1)$ and $4 \mathrm{~h}(\mathrm{PA}+\mathrm{HT} 2)$ ) conditions at $20^{\circ} \mathrm{C}$ and (b) irradiated at $60^{\circ} \mathrm{C}$ and $300^{\circ} \mathrm{C}$ and tested at $20^{\circ} \mathrm{C}$ and $300^{\circ} \mathrm{C}$, respectively, to a dose level of $\sim 0.3 \mathrm{dpa}$ in the prime aged and overaged (at $600^{\circ} \mathrm{C}$ for $1 \mathrm{~h}(\mathrm{PA}+$ HT1)) conditions. 

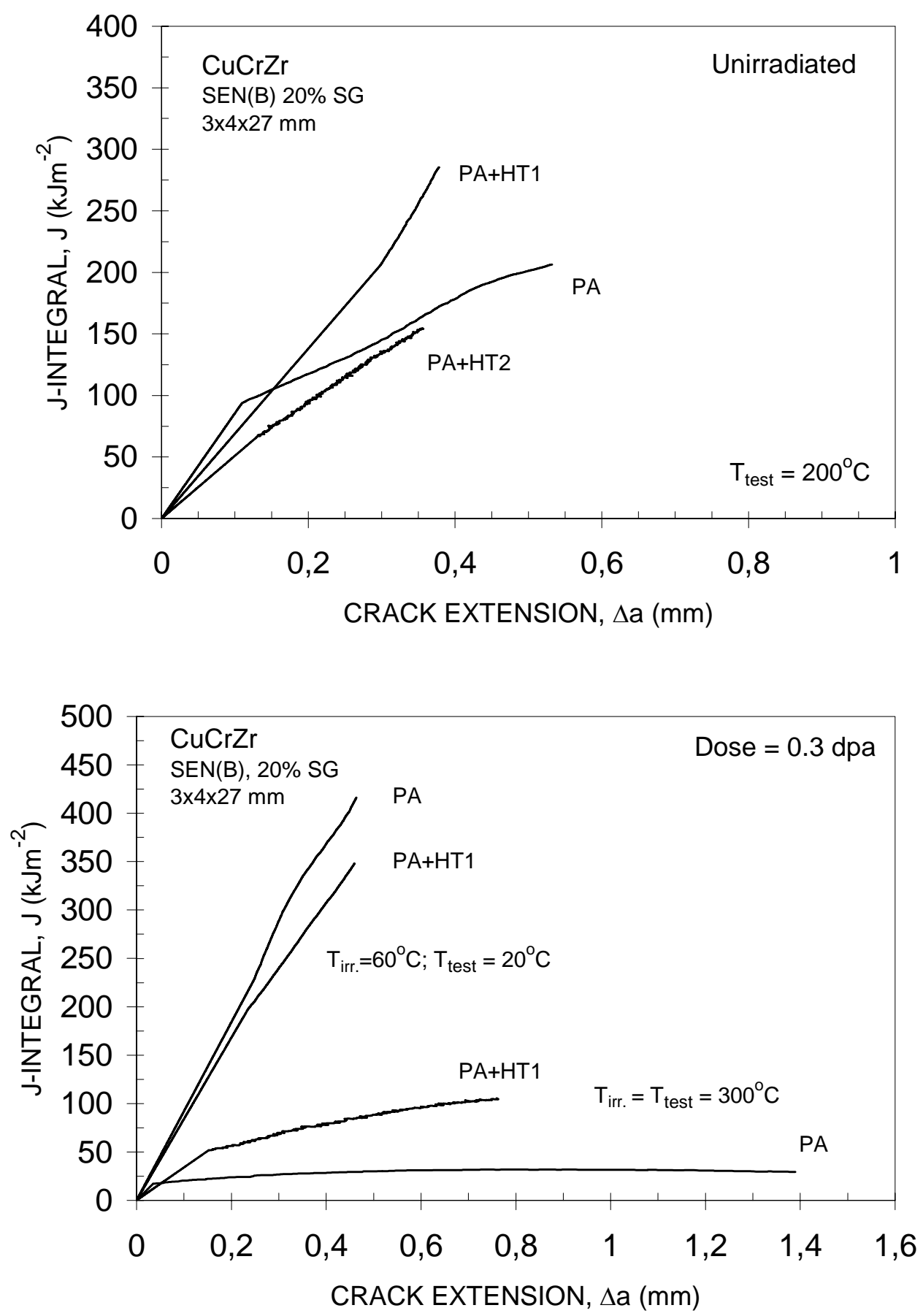

Figure 10. Fracture resistance curves of $\mathrm{CuCrZr}$ alloy (a) unirradiated in the prime aged and overaged (at $600^{\circ} \mathrm{C}$ for $1 \mathrm{~h}(\mathrm{PA}+\mathrm{HT} 1)$ and $4 \mathrm{~h}(\mathrm{PA}+\mathrm{HT} 2)$ ) conditions at $200^{\circ} \mathrm{C}$ and (b) irradiated at $60^{\circ} \mathrm{C}$ and $300^{\circ} \mathrm{C}$ and tested at $20^{\circ} \mathrm{C}$ and $300^{\circ} \mathrm{C}$, respectively, to a dose level of $\sim 0.3 \mathrm{dpa}$ in the prime aged and overaged (at $600^{\circ} \mathrm{C}$ for $1 \mathrm{~h}$ (PA $+\mathrm{HT} 1$ )) conditions. 


\section{Mission}

To promote an innovative and environmentally sustainable technological development within the areas of energy, industrial technology and bioproduction through research, innovation and advisory services.

\section{Vision}

Risø's research shall extend the boundaries for the understanding of nature's processes and interactions right down to the molecular nanoscale.

The results obtained shall set new trends for the development of sustainable technologies within the fields of energy, industrial technology and biotechnology.

The efforts made shall benefit Danish society and lead to the development of new multi-billion industries. 